\title{
PALB2 Gene Mutation
}

National Cancer Institute

\section{Source}

National Cancer Institute. PALB2 Gene Mutation. NCI Thesaurus. Code C101641.

A molecular genetic abnormality that refers to a change in the nucleotide sequence of the PALB2 gene. 